\title{
Application of factor analysis in the assessment of groundwater quality in a blackfoot disease area in Taiwan
}

\author{
Chen-Wuing Liu, Kao-Hung Lin, Yi-Ming Kuo* \\ Department of Bioenvironmental Systems Engineering, National Taiwan University, Taipei 10617, Taiwan, ROC
}

\begin{abstract}
Factor analysis is applied to 28 groundwater samples collected from wells in the coastal blackfoot disease area of Yun-Lin, Taiwan. Correlations among 13 hydrochemical parameters are statistically examined. A two-factor model is suggested and explains over $77.8 \%$ of the total groundwater quality variation. Factor 1 (seawater salinization) includes concentrations of EC, TDS, $\mathrm{Cl}^{-}, \mathrm{SO}_{4}^{2-}, \mathrm{Na}^{+}, \mathrm{K}^{+}$and $\mathrm{Mg}^{2+}$, and Factor 2 (arsenic pollutant) includes concentrations of Alk, TOC and arsenic. Maps are drawn to show the geographical distribution of the factors. These maps delineate high salinity and arsenic concentrations. The geographical distribution of the factor scores at individual wells does not reveal the sources of the constituents, which are instead, deduced from geological and hydrological evidence. The areas of high seawater salinization and arsenic pollution correspond well to the groundwater overpumping area. Over-pumping of the local groundwater causes land subsidence and gradual salinization by seawater. The over-pumping also introduces excess dissolved oxygen that oxidizes the immobile minerals, releases arsenic by reductive dissolution of arsenic-rich iron oxyhydroxides and increases the arsenic concentration in water. The overextraction of groundwater is the major cause of groundwater salinization and arsenic pollution in the coastal area of Yun-Lin, Taiwan.
\end{abstract}

(c) 2003 Elsevier Science B.V. All rights reserved.

Keywords: Factor analysis; Salinization; Arsenic pollutant; Groundwater quality; Blackfoot disease

\section{Introduction}

The composition of groundwater is influenced by many processes, including wet and dry depositions of atmospheric salts, evapotranspiration, and water-soil and water-rock interactions. Many data concerning groundwater quality are required to identify groundwater masses. Advanced procedures must be applied, because the complexities of the regional hydrogeological conditions and

*Corresponding author. Tel.: +886-2-23626480; fax: + 886-2-23639557.

E-mail address: 1cw@gwater.agec.ntu.edu.tw (Y.-M. Kuo). hydrochemical processes that occur in aquifers are difficult to explain and document. The use of graphical methods such as the Stiff diagram (Stiff, 1951) to interpret aquatic chemistry is limited to two dimensions (Hem, 1970). Hydrochemists have thus applied factor analysis to interpret observed relationships among variables, to yield simpler relationships that provide insight into the underlying structure of the variables, to assess controls on groundwater composition, and to evaluate the spatial distribution of the studied pollutants (Matalas and Reiher, 1967). Factor analysis can identify several pollution factors reasonably, but the inter- 
pretation of these factors in terms of actual controlling sources and processes is highly subjective. However, factor analysis furnished the critical information on chemical relationships basic to the deduction. Factor analysis has been applied to several fields of geology, including petrography (Saager and Esselaar, 1969), geochemistry (Morsy, 1993; Reeve et al., 1996), and environmental geology (Voudouris et al., 1997).

Arsenic, transported mainly by water, is a ubiquitous element widely distributed in the environment. Humans are exposed to inorganic and organic arsenic through environmental, medicinal, and occupational exposures (USPHS, 1989). The main source of arsenic exposure for the general population is through ingestion of water that contains inorganic arsenic.

Arsenic has been well documented as one of the major risk factors for blackfoot disease. Blackfoot disease was once common in the southwestern coast of Taiwan (Chiou, 1996). The residents had used a high-arsenic artesian well for more than 50 years (Tseng, 1977). A large-scale correlative study on the association between arsenic complexes in well water and age-adjusted mortality from diabetes (Lai et al., 1994), hypertension (Chen et al., 1995), and cancers of the nasal cavity, lung, liver, bladder, kidney, and prostate (Chen and Wang, 1990) yields consistent findings. Patients with blackfoot disease had a significantly increased incidence of cancer, after adjustment for cumulative arsenic exposure.

Physical and chemical characteristics of drinking water, such as $\mathrm{pH}$ level and levels of arsenic, sodium, calcium, magnesium, manganese, iron, lead, nitrite and nitrite nitrogen, and bicarbonate, have been intensively studied in endemic areas of blackfoot disease (Yeh and Yang, 1980). Liu (1986) confirmed that the fluorescent substances in the artesian well water in areas of endemic blackfoot disease, are organic metallic complexes. Fluorescent compounds possessing polymerization, multiplicity, free radical, and metal elements which have similar functional groups, are defined as humic substances (Lu et al., 1988) suspected to be associated with development of blackfoot disease (Lu, 1990).
Humic substances possess polymers of many anions presenting intense chelating ability and combining with metals of positive valence, compounds and toxicant. A benzene ring is the nucleus of humic substances, which are easy to combine with metal group to become organic metallic complexes and pesticides. The high reactivity of free radicals can severely damage biological proteins and DNA (Zhang and Snyder, 1992; Lynn et al., 1998). Atomic absorption spectrophotometry analysis (Liu, 1986) further revealed fluorescent compounds that contained arsenic and other metals such as $\mathrm{Fe}, \mathrm{Mn}, \mathrm{Pb}, \mathrm{Cd}, \mathrm{Zn}$ and Ni. Anawar et al. (2002a) found a high concentration of fluorescent humic substances in drinking water that contained elevated concentrations of arsenic and traces of heavy metals.

Researchers also have reported that groundwater contamination by arsenic is attributed to the excessive use of large varieties of pesticide and the rural electrification program (Bagla and Kaiser, 1996) or oxidation of pyrite by atmospheric oxygen introduced into groundwater due to tube-well pumping (Das et al., 1996). Furthermore, Nickson et al. (1998) and Acharyya et al. (1999) proposed that reductive dissolution of iron oxyhydroxide is the main source of arsenic in groundwater of Bangladesh.

Due to the shortage of surface water mainly from limited rivers and creeks, groundwater is a major water resource in the Yun-Lin county of Taiwan. The over-pumping of groundwater for aquaculture leads to land subsidence, seawater intrusion, and soil salinization in the coastal of Yun-Lin (Liu et al., 2001). The over-pumping also introduces excess dissolved oxygen that may oxidize the immobile mineral, releases arsenic and increases the arsenic concentration in water.

This study attempts to employ the factor analysis to identify useful pollution indicators for prospecting and delineating the boundaries of seawater salinization and arsenic pollution in a blackfoot disease area of Taiwan. The factor model may also describe the main hydrochemical processes and identify the possible cause of groundwater salinization and arsenic pollution in the coastal aquifer of Yun-Lin. 


\section{Study area}

Yun-Lin County is located in the southwestern part of the alluvial fan of the Chou-Shui River (Fig. 1). The area is enclosed by the Taiwan Strait to the west, the central mountains to the east, the Chou-Shui River to the north and the Pei-Kong river to the south. Chou-Shui and Pei-Kong are the two major rivers that flow through the area. The area is approximately $1000 \mathrm{~km}^{2}$, and extends $48 \mathrm{~km}$ from east to west and $24 \mathrm{~km}$ from north to south. The average annual precipitation is 1416.8 $\mathrm{mm}$. Rainfall is concentrated in the 5-month period from May to September.

Agriculture is the primary source of revenue in Yun-Lin. The industrial sector has rapidly grown, causing the average income of farmers to fall significantly below that of workers in other sectors. Consequently, many farmers have converted their croplands into fishponds to boost earnings. A large quantity of groundwater has been extracted from the aquifer to supply these fishponds. The extraction has caused serious land subsidence, seawater intrusion, flooding and deterioration of the surrounding environment (Tsao and Wang, 1984; Shen, 1989; Geng et al., 1994). According to Chen (1997), the vertical infiltration and the lateral intrusion of seawater are the main causes of local groundwater salinization. Moreover, seawater infiltration from fishponds is the major vertical infiltration source of shallow groundwater salinization in the coastal area of Yun-Lin.

Inhabitants of the coastal area of Yun-Lin now drink tap water; however, the groundwater is still used for aquaculture. The variation in arsenic concentration is important since the intensively pumped groundwater for aquacultural uses may enter the food-chain and trigger blackfoot disease again. Lin et al. (2001) examined the bioaccumulation of arsenic in Liza macrolepis to assess arsenic concentration in fish tissue. Their results establish that muscle has a high arsenic concentration, similar to that in the liver and the gill, suggesting that arsenic metabolism in fish is importantly involved in the accumulation of arsenic in fish tissue. The fish culturing industry of Liza macrolepis is vulnerable to the effects of arsenic pollution since the use of groundwater for aqua- culture may cause overexposure to arsenic. Arsenic can be accumulated in fish tissue, and fish are primary sources of arsenic when consumed. Thus, the consumption of cultured fish from an area with blackfoot disease may pose a risk to human health.

Twenty-eight groundwater monitoring wells, including 21 shallow wells and seven deep wells have been constructed along the coastal blackfoot disease region of Yun-Lin (Fig. 1). These wells were designed to monitor the quality of groundwater with an emphasis on arsenic pollution and aquifer salinization, and potential groundwater contamination in the coastal area. The depth of the wells ranged from $8 \mathrm{~m}$ to $110 \mathrm{~m}$. Groundwater samples were collected seasonally between 1992 and 1998 (Tainan Hydraulic Laboratory, 19921998). This study analyzes the samples collected in July (the third season) of 1997. Analyses of other seasonal samples yield similar results. Groundwater with a volume of three wells was purged before sampling. Samples were then collected at the outflow of wellpump in polyethylene bottles. Unstable parameters such as temperature and electrical conductivity (EC) were measured in the field. Other parameters, alkalinity (Alk), the concentrations of total dissolved solid (TDS), arsenic (As), total organic carbon (TOC), sulfates $\left(\mathrm{SO}_{4}^{2-}\right), \mathrm{Cl}^{-}, \mathrm{NO}_{3}^{-}-\mathrm{N}, \mathrm{Na}^{+}, \mathrm{K}^{+}, \mathrm{Mg}^{2+}$ and $\mathrm{Ca}^{2+}$, and the total hardness (TH), were analyzed in the laboratory. Table 1 lists the analytical methods and detection limits. The ionic charge balance of each sample was within $\pm 5 \%$. Table 2 presents analytical results.

\section{Factor analysis}

Factor analysis, a multivariate statistical method, yields the general relationship between measured chemical variables by showing multivariate patterns that may be help to classify the original data. It enables the geographical distribution of the resulting factors to be determined. The geological interpretation of factors yields insight into the main processes, which may govern the distribution of hydrochemical variables.

The hydrochemical data were statistically analyzed. The first step was to standardize the raw data to form Table 2 . Let $x_{i}, \ldots, x_{p}$ denote $P$ varia- 


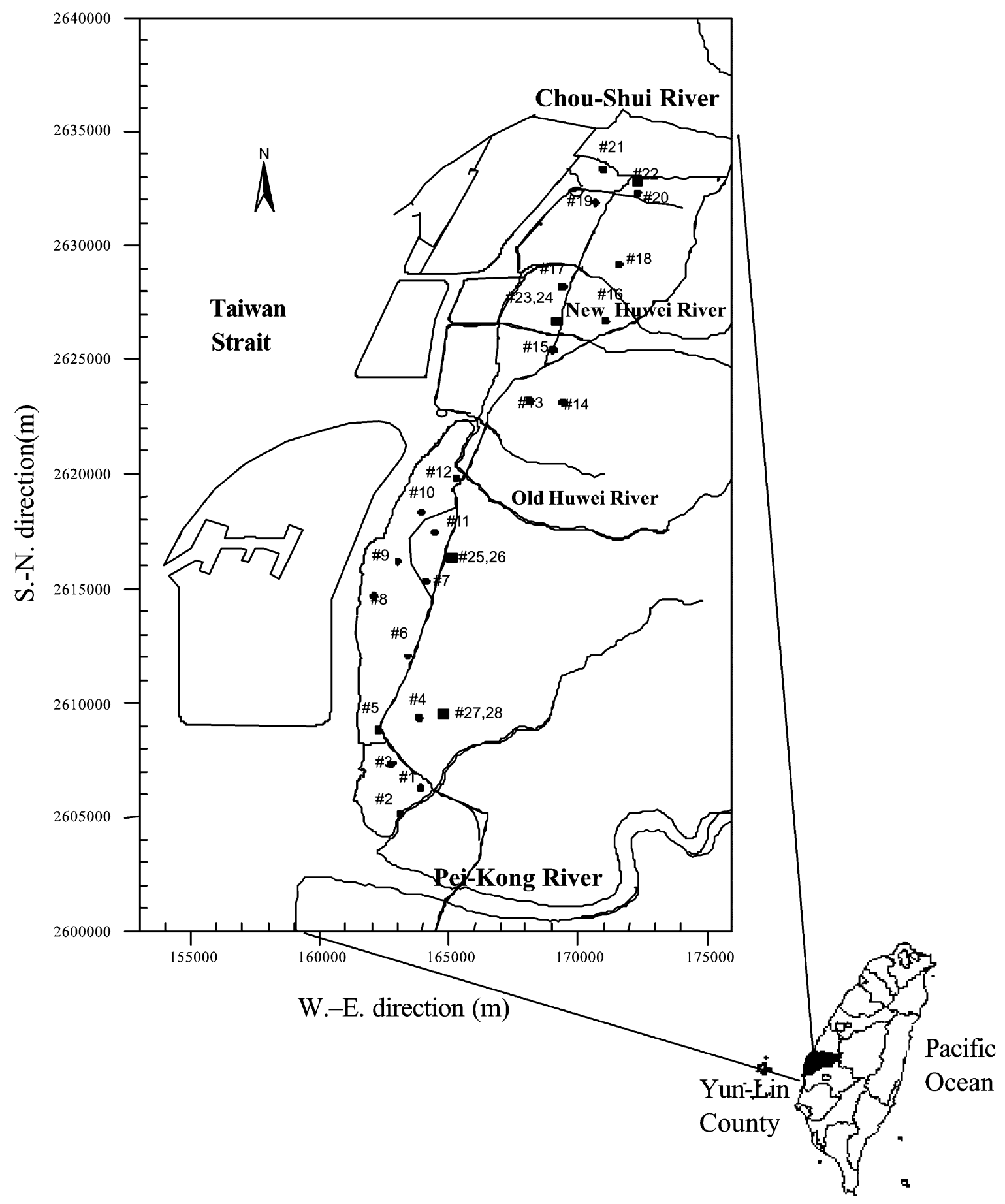

Fig. 1. Locations of 28 wells in Yun-Lin coastal area, Taiwan. 
Table 1

Analytical method and detection limits

\begin{tabular}{llll}
\hline Item & Method & Description & $\begin{array}{c}\text { Detection } \\
\text { Limit } \\
(\mathrm{mg} / 1)\end{array}$ \\
\hline E.C. & NIEA W203.50A & Conductivity Meter & - \\
$\mathrm{Alk}$ & APHA 2320B & Titrimetric & 0.5 \\
$\mathrm{TDS}$ & APHA 1030F & Calculation:form conductivity & - \\
$\mathrm{Cl}^{-}$ & NIEA.W407.50A & Titrimetric(mercuric nitrate) & 0.5 \\
$\mathrm{SO}_{4}^{2-}$ & NIEA W430.50A & Turbidimetric & 0.19 \\
$\mathrm{NO}_{3}^{-}-\mathrm{N}$ & NIEA W419.50A & Spectrophotometric & 0.075 \\
$\mathrm{TOC}^{+}$ & APHA 5310C & Oxidation/NDIR detection & 0.55 \\
$\mathrm{Na}^{+}$ & APHA 3500-Na B & Flame AA & 0.23 \\
$\mathrm{~K}^{+}$ & APHA 3500-K B & Flame AA & 0.1 \\
$\mathrm{As}^{2+}$ & APHA 3500-As B & Hydride Generation-AA & 0.06 \\
$\mathrm{Ca}^{2+}$ & APHA 3500-Mg B & Flame AA & 0.26 \\
$\mathrm{TH}$ & APHA 3500-Ca B & Flame AA & 0.25 \\
\hline
\end{tabular}

Table 2

Data matrix for 28 groundwater sample concentrations [in $\mathrm{mg} / 1$, except for E.C. $(\mu \mathrm{S} / \mathrm{cm})$ and As $(\mu \mathrm{g} / 1)$ ]

\begin{tabular}{|c|c|c|c|c|c|c|c|c|c|c|c|c|c|}
\hline No. & E.C. & Alk & TDS & $\mathrm{Cl}^{-}$ & $\mathrm{SO}_{4}^{2-}$ & $\mathrm{NO}^{-}-\mathrm{N}$ & TOC & $\mathrm{Na}^{+}$ & $\mathrm{K}^{+}$ & As & $\mathrm{Mg}^{2+}$ & $\mathrm{Ca}^{2+}$ & $\mathrm{TH}$ \\
\hline$\# 1$ & 2390 & 482 & 1676 & 399 & 218 & 0.21 & 1.53 & 259 & 41 & 3.4 & 72 & 119 & 593 \\
\hline$\# 2$ & 39500 & 387 & 35140 & 13789 & 1813 & 0.52 & 2.05 & 9104 & 494 & 17.6 & 1413 & 61 & 5971 \\
\hline \#3 & 22900 & 395 & 18620 & 7713 & 345 & 0.25 & 1.16 & 4255 & 207 & 61.0 & 873 & 541 & 4946 \\
\hline \#4 & 14660 & 384 & 11890 & 4594 & 255 & 0.18 & 1.07 & 2275 & 117 & 24.9 & 342 & 242 & 2011 \\
\hline$\# 5$ & 808 & 378 & 566 & 37 & 18 & 0.40 & 1.07 & 43 & 9 & 5.4 & 52 & 68 & 384 \\
\hline \#6 & 15310 & 539 & 12500 & 4914 & 680 & 0.80 & 3.00 & 2655 & 138 & 245.0 & 197 & 58 & 565 \\
\hline \#7 & 2760 & 650 & 1932 & 540 & 100 & 0.00 & 3.89 & 333 & 41 & 226 & 102 & 59 & 2699 \\
\hline$\# 8$ & 27200 & 359 & 23360 & 9109 & 1502 & 0.25 & 0.71 & 4470 & 169 & 7.0 & 620 & 243 & 636 \\
\hline \#9 & 3010 & 756 & 2210 & 414 & 270 & 0.90 & 18.03 & 646 & 33 & 558.0 & 7 & 2 & 3373 \\
\hline$\# 10$ & 36700 & 318 & 32020 & 12642 & 2029 & 0.45 & 0.53 & 5690 & 266 & 7.9 & 818 & 368 & 919 \\
\hline \#11 & 1112 & 421 & 778 & 103 & 0 & 0.00 & 1.97 & 131 & 42 & 90.4 & 25 & 17 & 147 \\
\hline$\# 12$ & 18130 & 400 & 14700 & 5722 & 990 & 0.28 & 0.87 & 2550 & 91 & 36.4 & 284 & 282 & 1874 \\
\hline \#13 & 8740 & 368 & 6810 & 2522 & 527 & 0.0 & 0.84 & 1642 & 91 & 20.0 & 286 & 291 & 1904 \\
\hline$\# 14$ & 1522 & 488 & 1065 & 115 & 192 & 0.98 & 1.82 & 234 & 16 & 31.8 & 15 & 12 & 93 \\
\hline$\# 15$ & 9220 & 456 & 7200 & 2621 & 611 & 0.24 & 1.50 & 1296 & 49 & 2.3 & 210 & 271 & 1541 \\
\hline$\# 16$ & 1523 & 444 & 1066 & 63 & 434 & 1.07 & 0.64 & 48 & 5 & 1.7 & 64 & 237 & 855 \\
\hline \#17 & 2630 & 336 & 1841 & 552 & 171 & 6.37 & 0.78 & 324 & 20 & 4.2 & 30 & 146 & 488 \\
\hline$\# 18$ & 1564 & 346 & 1095 & 105 & 677 & 0.0 & 1.01 & 81 & 16 & 8.5 & 75 & 173 & 738 \\
\hline \#19 & 11970 & 566 & 5855 & 3747 & 265 & 0.23 & 3.48 & 2760 & 93 & 28.2 & 265 & 97 & 1331 \\
\hline$\# 20$ & 1427 & 366 & 998 & 72 & 325 & 0.0 & 0.92 & 64 & 4 & 4.9 & 43 & 207 & 693 \\
\hline$\# 21$ & 969 & 279 & 678 & 59 & 181 & 0.12 & 1.80 & 73 & 12 & 7.2 & 43 & 62 & 332 \\
\hline$\# 22$ & 568 & 266 & 398 & 5 & 37 & 0.28 & 1.45 & 43 & 4 & 255.0 & 18 & 56 & 213 \\
\hline$\# 23$ & 525 & 266 & 368 & 6 & 24 & 0.72 & 0.48 & 34 & 16 & 11.4 & 30 & 21 & 176 \\
\hline \#24 & 528 & 258 & 370 & 13 & 25 & 0.24 & 0.91 & 56 & 2 & 19.9 & 11 & 57 & 188 \\
\hline$\# 25$ & 853 & 451 & 597 & 9 & 3 & 1.67 & 3.13 & 136 & 33 & 113.0 & 21 & 11 & 111 \\
\hline \#26 & 447 & 248 & 313 & 5 & 0 & 0.0 & 1.28 & 51 & 2 & 66.6 & 6 & 33 & 107 \\
\hline \#27 & 663 & 364 & 464 & 13 & 31 & 1.89 & 3.50 & 28 & 38 & 21.9 & 15 & 63 & 219 \\
\hline \#28 & 758 & 334 & 531 & 37 & 6 & 6.36 & 3.33 & 64 & 12 & 46.0 & 17 & 66 & 237 \\
\hline
\end{tabular}


bles, each with $N$ observations. The $j$ th observation of the $i$ th variable is $X_{i, j}$, where $i=1, \ldots, P$ and $j=$ $1, \ldots, N$. If $x_{m}$ and $S_{i}$ denote the mean and standard deviation, respectively, computed from the $N$ observations of the $i$ th variable, then the $j$ th observation of the $i$ th variable is expressed in standardized units as,

$Z_{i j}=\frac{X_{i, j}-x_{m}}{S_{i}}$

where $Z_{i j}$ is the $j$ th value of the standardized variable, $Z_{i}$. The mean and variance of $Z_{i}$ are zero and one, respectively, for all values of $i$. Standardization tends to increase the influence of variables whose variance is small, and reduce the influence of variables whose variance is large. Furthermore, the standardization procedure eliminates the influence of different units of measurement, and makes the data dimensionless.

Factor analysis takes data contained in a correlation matrix and rearranges them in a manner that better explains the structure of the underlying system that produced the data. Therefore, the correlation coefficient matrix measures how well the variance of each constituent can be explained by relationships with each of the others. Then, the variances/co-variances and correlation coefficients of the variables are computed, the correlation coefficient is:

$r_{x, y}=\frac{\sum\left(x-x_{m}\right)\left(y-y_{m}\right)}{\sqrt{\left[\sum\left(x-x_{m}\right)\right]^{2}\left[\sum\left(y-y_{m}\right)\right]^{2}}}$

In this expression the correlation coefficients $\left(r_{x, y}\right)$ is simply the sum (over all samples) of the products of the deviations of the $x$-measurements and the $y$-measurements on each sample, from the mean values of $x$ and $y$, respectively, for the complete set of samples. Table 3 presents the matrix of correlation coefficient for hydrochemical data in Yun-Lin.

Eigenvalues and eigenvectors were calculated for the covariance matrix. Then, the data were transformed into factors. Table 4 presents the eigenvalue and the percentages of variance asso- ciated with each factor. These values are summed to express as a cumulative eigenvalue and percentage of variance, respectively.

The number of factors extracted is to be determined. This study retains only factors with eigenvalues that exceed one. This criterion was proposed by Kaiser (1958) and is probably the one most widely used (Matalas and Reiher, 1967; Davis, 1987; Reyment and Joreskog, 1993). Moreover, the rotation of the factor axis is executed to yield a 'simple structure'; that is, factors that are somehow clearly marked by high loadings for some variables and low loadings for others, facilitating interpretation in terms of original variables. In this study, Kaiser's varimax rotation scheme was employed (Kaiser, 1958) and a two-factor model is determined. Table 5 shows the rotated factor matrix of the two-factor model. The factor loadings correlate the factors and the variables. They represent the most important information on which the interpretation of factors is based. High loading variables were marked by a star symbol in the two-factor model.

The contribution of each factor at every site (factor scores) is computed. Factor scores are projections of data onto corresponding eigenvectors. Factor scores can be thought of as the actual values of each well on the underlying factors. Factor scores were calculated for all 28 monitoring wells (Table 6). The distribution of factor scores and the residual variables are expressed in standard deviation units. Figs. 2 and 3 map the geographical distribution of the two factors.

\section{Results and discussion}

Table 4 presents the eigenvalues, the percentage of variance, the cumulative eigenvalue and the cumulative percentage of variance associated with each other. It reveals that the first two factors explain approximately $77.8 \%$ of total variance. Table 5 shows the loading of vaimax rotated factor matrix for two-factor model. Evidently, the first factor is generally more correlated with the variables than the second factor. This is to be expected because these factors are extracted successively, each one accounting for as much of the remaining variance as possible. 
Table 3

Matrix of correlation coefficients for hydrochemical data in Yun-Lin coastal area, Taiwan

\begin{tabular}{|c|c|c|c|c|c|c|c|c|c|c|c|c|c|}
\hline & E.C. & Alk & TDS & $\mathrm{Cl}^{-}$ & $\mathrm{SO}_{4}^{2-}$ & $\mathrm{NO}_{3}{ }^{-}-\mathrm{N}$ & TOC & $\mathrm{Na}^{+}$ & $\mathrm{K}^{+}$ & As & $\mathrm{Mg}^{2+}$ & $\mathrm{Ca}^{2+}$ & $\mathrm{TH}$ \\
\hline E.C. & 1.000 & -0.002 & 0.996 & 0.999 & 0.897 & -0.188 & -0.135 & 0.977 & 0.933 & -0.136 & 0.943 & 0.535 & 0.606 \\
\hline Alk & & 1.000 & -0.034 & -0.025 & -0.037 & -0.101 & 0.703 & 0.025 & 0.026 & 0.627 & -0.050 & -0.142 & 0.358 \\
\hline TDS & & & 1.000 & 0.997 & 0.909 & -0.178 & -0.141 & 0.972 & 0.939 & -0.135 & 0.946 & 0.517 & 0.600 \\
\hline $\mathrm{Cl}^{-}$ & & & & 1.000 & 0.894 & -0.182 & -0.146 & 0.979 & 0.939 & -0.145 & 0.948 & 0.521 & 0.600 \\
\hline $\mathrm{SO}_{4}^{2-}$ & & & & & 1.000 & -0.194 & -0.139 & 0.851 & 0.803 & -0.167 & 0.801 & 0.457 & 0.414 \\
\hline $\mathrm{NO}_{3}{ }^{-}-\mathrm{N}$ & & & & & & 1.000 & 0.067 & -0.176 & -0.156 & -0.049 & -0.190 & -0.150 & -0.191 \\
\hline TOC & & & & & & & 1.000 & -0.090 & -0.078 & 0.848 & -0.157 & -0.339 & 0.284 \\
\hline $\mathrm{Na}^{+}$ & & & & & & & & 1.000 & 0.979 & -0.113 & 0.973 & 0.427 & 0.687 \\
\hline $\mathrm{K}^{+}$ & & & & & & & & & 1.000 & -0.098 & 0.970 & 0.345 & 0.716 \\
\hline As & & & & & & & & & & 1.000 & -0.183 & -0.336 & 0.226 \\
\hline $\mathrm{Mg}^{2+}$ & & & & & & & & & & & 1.000 & 0.507 & 0.745 \\
\hline $\mathrm{Ca}^{2+}$ & & & & & & & & & & & & 1.000 & 0.379 \\
\hline TH & & & & & & & & & & & & & 1.000 \\
\hline
\end{tabular}


Table 4

Eigenvalues, percent of variance, cumulative eigenvalue, cumulative percent of variance for the factor analysis of hydrochemical data in Yun-Lin coastal area, Taiwan

\begin{tabular}{rlrrr}
\hline Factor & Eigenvalue & $\begin{array}{l}\text { Percent of } \\
\text { variance }\end{array}$ & $\begin{array}{l}\text { Cumulative } \\
\text { eigenvalue }\end{array}$ & $\begin{array}{l}\text { Cumulative } \\
\text { percent of } \\
\text { variance }\end{array}$ \\
\hline 1 & 7.4245 & 57.1113 & 7.4245 & 57.1113 \\
2 & 2.6908 & 20.6987 & 10.1153 & 77.8100 \\
3 & 0.9958 & 7.6598 & 11.1111 & 85.4698 \\
4 & 0.7346 & 5.6505 & 11.8456 & 91.1202 \\
5 & 0.5048 & 3.8831 & 12.3504 & 95.0033 \\
6 & 0.3675 & 2.8270 & 12.7179 & 97.8303 \\
7 & 0.1506 & 1.1583 & 12.8685 & 98.9886 \\
8 & 0.0905 & 0.6962 & 12.9590 & 99.6848 \\
9 & 0.0220 & 0.1695 & 12.9810 & 99.8542 \\
10 & 0.0100 & 0.0770 & 12.9911 & 99.9312 \\
11 & 0.0082 & 0.0627 & 12.9992 & 99.9939 \\
12 & 0.0007 & 0.0056 & 12.9999 & 99.9995 \\
13 & 0.0001 & 0.0005 & 13.0000 & 100.0000 \\
\hline
\end{tabular}

The terms 'strong', 'moderate', and 'weak' as applied to factor loadings, refer to absolute loading values of $>0.75,0.75-0.5$ and $0.5-0.3$, respectively. Factor 1, which explains $56.9 \%$ of the total variance (Table 5), has strong positive loadings on EC, TDS, $\mathrm{Cl}^{-}, \mathrm{SO}_{4}^{2-}, \mathrm{Na}^{+}, \mathrm{K}^{+}$and $\mathrm{Mg}^{2+}$ and moderate loadings on $\mathrm{Ca}^{2+}$ and TH. EC, TDS, $\mathrm{Cl}^{-}, \mathrm{SO}_{4}^{2-}, \mathrm{Na}^{+}, \mathrm{K}^{+}$and $\mathrm{Mg}^{2+}$ are the major

Table 5

Loading for varimax rotated factor matrix of two-factor model explaining $77.8 \%$ of the total variance

\begin{tabular}{lcr}
\hline Variable & Factor 1 & Factor 2 \\
\hline E.C. & $0.9844^{\mathrm{a}}$ & 0.0619 \\
$\mathrm{Alk}$ & 0.0454 & $-0.8449^{\mathrm{a}}$ \\
$\mathrm{TDS}$ & $0.9830^{\mathrm{a}}$ & 0.0736 \\
$\mathrm{Cl}^{-}$ & $0.9835^{\mathrm{a}}$ & 0.0757 \\
$\mathrm{SO}_{4}{ }^{2-}$ & $0.8786^{\mathrm{a}}$ & 0.1120 \\
$\mathrm{NO}_{3}^{-}-\mathrm{N}$ & -0.2287 & 0.0626 \\
$\mathrm{TOC}^{+}$ & -0.0883 & $-0.9349^{\mathrm{a}}$ \\
$\mathrm{Na}^{+}$ & $0.9849^{\mathrm{a}}$ & 0.0021 \\
$\mathrm{~K}^{+}$ & $0.9603^{\mathrm{a}}$ & -0.0233 \\
$\mathrm{As}^{\mathrm{a}}$ & -0.1040 & $-0.9025^{\mathrm{a}}$ \\
$\mathrm{Mg}^{2+}$ & $0.9755^{\mathrm{a}}$ & 0.0703 \\
$\mathrm{Ca}^{2+}$ & 0.5379 & 0.3321 \\
$\mathrm{TH}^{+}$ & 0.7183 & -0.4109 \\
\hline Eigenvalue & 7.3967 & 2.7186 \\
\hline Variance & 0.5690 & 0.2091 \\
\hline
\end{tabular}

${ }^{\mathrm{a}}$ Absolute loading values $>0.85$.
Table 6

Scores for the two-factor model

\begin{tabular}{|c|c|c|}
\hline $\begin{array}{l}\text { Well } \\
\text { no. }\end{array}$ & $\begin{array}{l}\text { Factor } 1 \\
\text { (seawater } \\
\text { salinization) }\end{array}$ & $\begin{array}{l}\text { Factor } 2 \\
\text { (arsenic } \\
\text { pollutant) }\end{array}$ \\
\hline$\# 1$ & -0.4405 & 0.0774 \\
\hline$\# 2$ & 3.1970 & -0.3992 \\
\hline \#3 & 1.5765 & 0.0676 \\
\hline \#4 & 0.4596 & 0.2755 \\
\hline$\# 5$ & -0.6538 & 0.3759 \\
\hline \#6 & 0.3949 & -0.9238 \\
\hline \#7 & -0.2764 & -1.5267 \\
\hline$\# 8$ & 1.3855 & 0.6484 \\
\hline$\# 9$ & -0.2174 & -4.3250 \\
\hline \#10 & 2.1895 & 0.8733 \\
\hline \#11 & -0.6389 & -0.1019 \\
\hline \#12 & 0.7079 & 0.3195 \\
\hline \#13 & 0.2362 & 0.4184 \\
\hline \#14 & -0.6328 & -0.0680 \\
\hline \#15 & 0.1415 & 0.2050 \\
\hline \#16 & -0.4302 & 0.3830 \\
\hline \#17 & -0.6225 & 0.6847 \\
\hline \#18 & -0.3940 & 0.5353 \\
\hline \#19 & 0.2026 & -0.5285 \\
\hline \#20 & -0.4843 & 0.5209 \\
\hline \#21 & -0.6308 & 0.5594 \\
\hline$\# 22$ & -0.7071 & -0.0459 \\
\hline \#23 & -0.7269 & 0.7053 \\
\hline$\# 24$ & -0.7219 & 0.6823 \\
\hline \#25 & -0.6906 & -0.3371 \\
\hline \#26 & -0.7452 & 0.5239 \\
\hline \#27 & -0.6772 & 0.1428 \\
\hline \#28 & -0.8007 & 0.2574 \\
\hline
\end{tabular}

solutes in seawater. The electrical conductivity (EC) is positively correlated with the concentration of ions, which can thus be indirectly calculated from EC. Therefore, EC can be regarded as a water salinization index. The association of $\mathrm{EC}$, TDS, $\mathrm{Cl}^{-}, \mathrm{SO}_{4}^{2-}, \mathrm{Na}^{+}, \mathrm{K}^{+}$and $\mathrm{Mg}^{2+}$ reflects the influence of seawater intrusion on pollution of groundwater and can thus be termed, 'the seawater salinization factor'.

According to Lambrakis et al. (1996) simultaneous drought and over-pumping have led to deterioration of the groundwater due to seawater intrusion. In the Yun-Lin coastal area, the shallow aquifer has suffered serious salinization where the concentrations of EC, TDS, $\mathrm{SO}_{4}^{2-}, \mathrm{Cl}^{-}$and $\mathrm{Na}^{+}$ far exceed the agricultural water quality standards because farmers have extracted large amounts of 


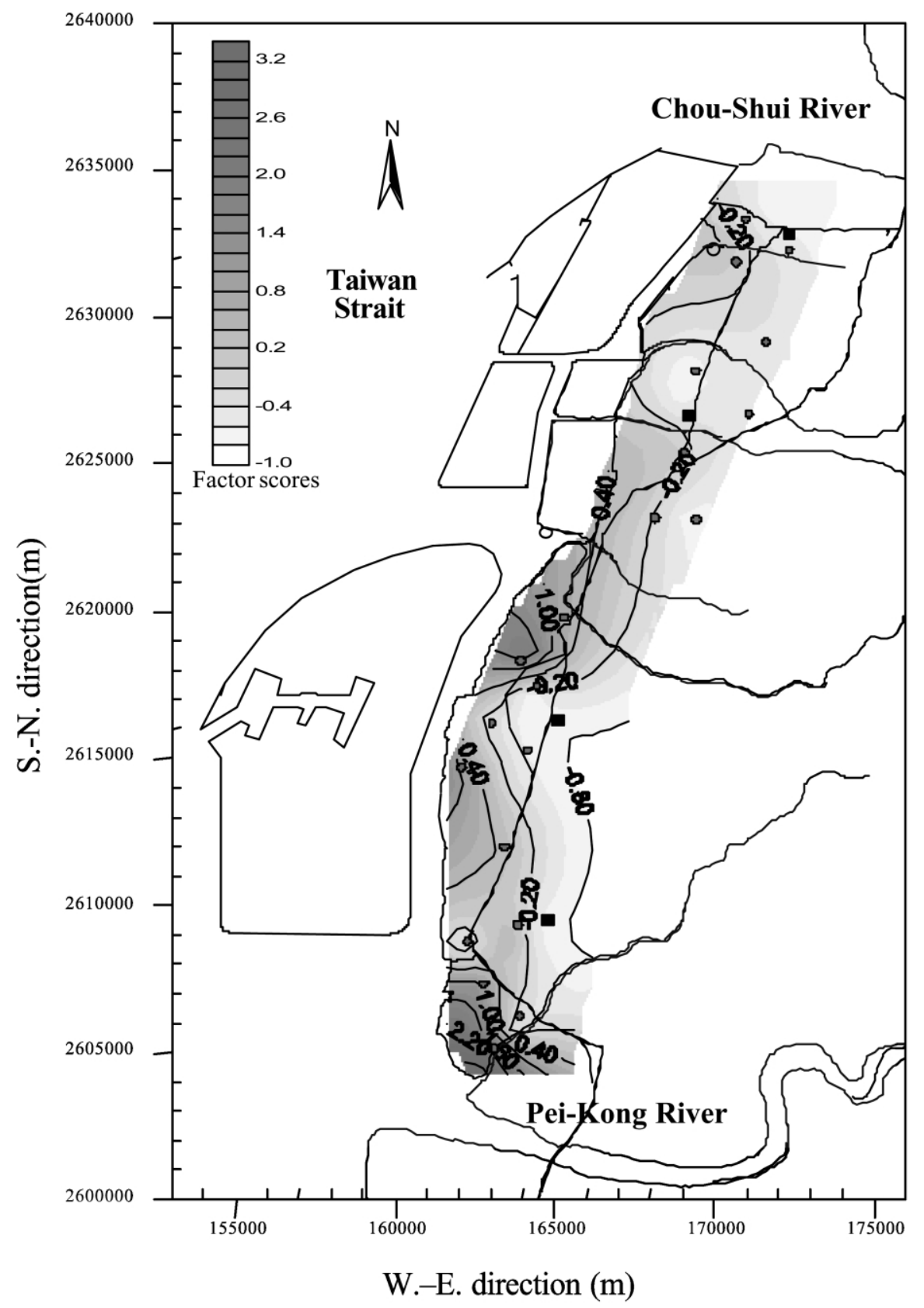

Fig. 2. Distribution of scores for factor 1 (seawater salinization); the darkly shaded areas (high scores) represent high seawater salinization.

groundwater from the aquifer for their fishponds. The high scores at wells 2, 3, 4, 6, 8, 10 and 12, which are the darkly shaded areas in Fig. 2, indicate severe seawater salinization. Two areas of high seawater salinization, one in the south of the Old Huwei River, and the other in the north of 


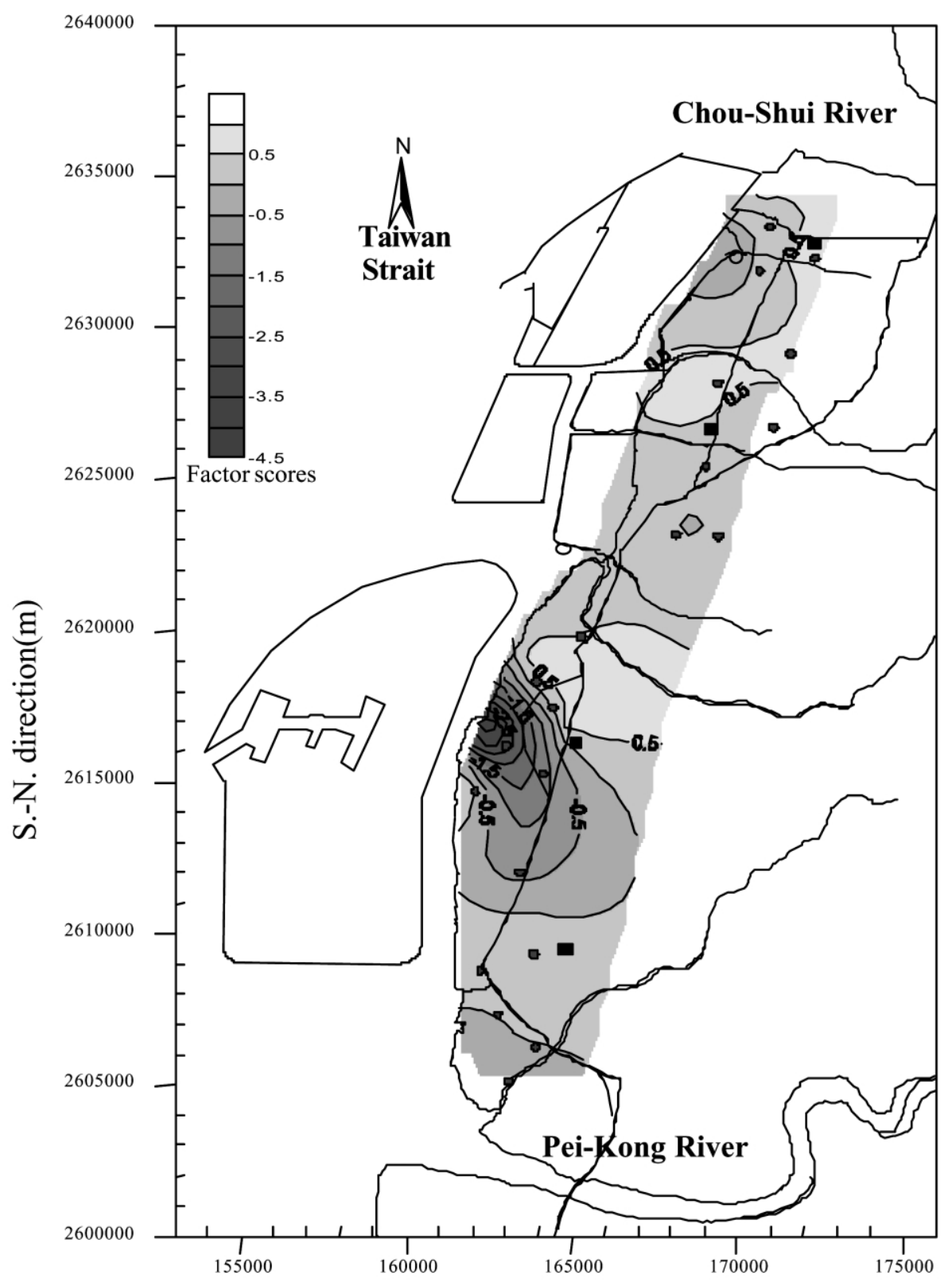

W.-E. direction (m)

Fig. 3. Distribution of scores for factor 2 (arsenic pollution); the darkly shaded areas (low scores) represent high arsenic pollution.

Pei-Kong River, correspond to the two most serious land subsidence areas in the coastal region (Gau et al., 2001). This finding confirms that the over-pumping of groundwater is the major cause of severe land subsidence and seawater salinization in Yun-Lin. The farmers should avoid extracting 
the large quantities of groundwater to prevent further seawater salinization and land subsidence.

Factor 2 explains $20.9 \%$ of the total variance (Table 5) with strong absolute loadings of Alk, TOC and arsenic. The association of Alk, TOC and arsenic reflects the influence of arsenic as a pollutant in the area and can thus be termed 'the arsenic pollutant factor'. The correlation coefficient between TOC and arsenic is 0.848 , that between Alk and arsenic is 0.627, and the correlation coefficient between TOC and Alk is 0.703 (Table 3). A similar result was reported by $\mathrm{Bi}$ (1996) who showed the correlation coefficient between arsenic and Alk was 0.6. Evidence suggests that TOC is the major factor that governs the liberation of arsenic. Arsenic is adsorbed on TOC near the redox boundary during oxidation, and then liberated from TOC by reductive dissolution/desorption, or by ion exchange involving seawater. Thus, the interaction between TOC and arsenic explains the distribution of arsenic in groundwater.

Anawar et al. (2002b) reported that most of the groundwater samples contain high concentrations of arsenic, dissolved iron, ammonium, phosphate, and bicarbonate and low concentrations of sulfate and nitrate reflecting the reducing condition of groundwater. Arsenic may derive from reductive dissolution iron and manganese oxyhydroxide and microbial oxidation of organic matter. Various heavy metal contaminants extracted from well water in areas of blackfoot disease are associated with humic acid. The synergistic effect of humic acid in groundwater may aggravate the toxicity of arsenic. Heavy metals have various redox states, and may therefore transfer or perpetuate free radical formation, aggravating the toxicity of arsenic or metallic complex compounds (Yang et al., 1998).

The arsenic content was high in the silty sand and silty clay sediments, which are generally enriched in $\mathrm{Fe}$ and $\mathrm{Mn}$ oxyhydroxides, organic carbon, clay minerals, and thus contain a higher concentration of As (Anawar et al., 2002b). The abundance of arsenic in clays may be a result of the inherent properties of clay minerals (Vine and Tourtelot, 1970) and the heterogeneous oxidation of $\mathrm{As}(\mathrm{III})$ to $\mathrm{As}(\mathrm{V})$ on clay mineral surfaces
(Manning and Goldberg, 1997) in alkaline solutions because the clay minerals, kaolinite and montmorillonite have higher adsorption affinities for As(V) than for As(III). The Yun-Lin plain is in the southwestern part of the alluvial fan of the Chou-Shui River and is formed from a thick succession of alluvial sediments weathered from the Central Mountains. The silty sand and clay were carried by rivers and deposited in the downstream coastal area. High arsenic concentrations in wells 2, 6, 7, 9 and 25 were accompanied by high contents of $\mathrm{Fe}$ and $\mathrm{Mn}$ oxyhydroxides, and clay minerals, which finding supports the above argument (Gau et al., 2001).

The safe level for arsenic in drinking water set by the Environmental Protection Administration of the Republic of China is $50 \mu \mathrm{g} / \mathrm{l}$. The low factor scores of wells 2, 6, 7, 9, 19 and 25 in the south of the Old Huwei River (darkly shaded areas in Fig. 3) represent high arsenic contamination. The areas of high arsenic concentration in the south of the Old Huwei River coincide with areas of the over-pumping of groundwater. The over-extraction of groundwater introduces excess dissolved oxygen that oxidizes the original immobile mineral, releasing arsenic ions by reductive dissolution of arsenicrich iron oxyhydroxides. Wells $6,7,9$ and 25 are shallow wells in which water quality frequently exceeds the current drinking water standard (50 $\mu \mathrm{g} / \mathrm{l})$. Local people should avoid using groundwater here since the reduced arsenic-rich minerals will be dissolved into the water (Das et al., 1996).

\section{Conclusions}

Factor analysis is an effective means of manipulating, interpreting, and representing data concerning groundwater pollutants. Factor analysis was applied to groundwater samples from an area of blackfoot disease. The results showed that a two-factor model-where factor 1 (seawater salinization) included $\mathrm{EC}, \mathrm{TDS}, \mathrm{Cl}^{-}, \mathrm{SO}_{4}^{2-}, \mathrm{Na}^{+}, \mathrm{K}^{+}$ and $\mathrm{Mg}^{2+}$, and factor 2 (arsenic pollution) included Alk, TOC and arsenic explained $77.8 \%$ of the variation in quality of groundwater. The model described the main hydrogeochemical processes in the coastal aquifer of Yun-Lin. The geographical distribution of the factor scores at individual wells 
delineated boundaries which define where groundwater is affected by seawater salinization and arsenic pollution. Areas of high scores for seawater salinization and arsenic pollution correspond well with areas of groundwater over-pumping. The overpumping of groundwater causes land subsidence, seawater intrusion and gradual salinization of the local groundwater. The over-pumping also introduces excess dissolved oxygen that oxidizes immobile mineral, releases arsenic ions by reductive dissolution arsenic-rich iron oxyhydroxides, and increases arsenic concentration in water. The overextraction of groundwater is the major cause of groundwater salinization and arsenic pollution in the coastal area of Yun-Lin, Taiwan.

\section{Acknowledgments}

The authors would like to thank the National Science Council of the Republic of China for financially supporting this research under contract no. NSC 90-2313-B-002-322.

\section{References}

Acharyya SK, Chakraborty P, Lahiri S, Raymahashay BC, Guha S, Bhowmik A. Arsenic poisoning in the Ganges delta. Nature 1999;401:545.

Anawar HM, Akai J, Mostofa KMG, Safiullah S, Tareq SM. Arsenic poisoning in groundwater health risk and geochemical sources in Bangladesh. Environ Int 2002a;27:597-604.

Anawar HM, Komaki K, Akai J, Takada J, Ishizuka T, Takahashi T, Yoshioka T, Kato K. Diagenetic control on arsenic partitioning in sediments of the Meghna River delta, Bangladesh. Environ Geol 2002b;41:816-825.

Bagla P, Kaiser J. India's spreading health crisis draws global arsenic experts. Science 1996;274:174-175.

Bi LL. A preliminary study on the arsenic enrichment of groundwater in Chianan area, Taiwan. Master Thesis. Taiwan: Institute of Geology, National Taiwan University, 1996. (pp. 50).

Chen CJ, Wang CJ. Ecological correlation between arsenic level in well water and aged-adjusted mortality from malignant neoplasms. Cancer Res 1990;50:5470-5474.

Chen CJ, Hsueh YM, Lai MS, Shyu MP, Chen SY, Wu MM, Kuo TL, Tai TY. Increased prevalence of hypertension and long-term arsenic exposure. Hypertension 1995;25:53-60.

Chen ST. Analysis of aquifer salinization in the coastal area of Yun-Lin. Master Thesis. Taiwan: Department of Agricultural Engineering, National Taiwan University, 1997. (pp. $55)$.
Chiou HY. Epidemiologic studies on inorganic arsenic methylation capacity and inorganic arsenic induced health effects among residents in the blackfoot disease endemic area and Lanyang basin in Taiwan. Doctoral Dissertation. Taiwan: Institute of Epidemiology, College of Public Health, National Taiwan University, 1996. (pp. 8).

Das D, Samanta G, Mandal BK, Chowdhury TR, Chanda CR, Chowdhury PP, Basu GK, Chakraborti D. Arsenic in groundwater in six districts of West Bengal, India. Environ Geochem Health 1996;18:5-15.

Davis JC. Statistics and data analysis in geology, 2nd ed. New York: John Wiley and Sons, 1987. p. 656.

Gau MS, Liu CW, Taso YS. Estimation of optimal yield in Yun-Lin area of Taiwan using decision analysis. J Am Water Resour Assoc 2001;34(6):1295-1309.

Geng CC, Hsueh CH, Kung CS. Modeling of the groundwater flow and land subsidence in Yun-Chia plain and Yun-Lin offshore industrial area. Conference on Groundwater Research and Quality Protection, Taiwan 1994. p. 453-472.

Hem JD. Study and interpretation of the chemical characteristics of natural water. U.S. Geology Survey Water-Supply Paper. 1970. (pp. 263).

Kaiser HF. The varimax criteria for analytical rotation in factor analysis. Psychometrika 1958;23(3):187-200.

Lai MS, Hsueh YM, Chen CJ, Shyu MP, Chen SY, Kuo TL, $\mathrm{Wu} \mathrm{MM}$, Tai TY. Ingested inorganic arsenic and prevalence of diabetes mellitus. Am J Epidemiol 1994;139:484-492.

Lambrakis N, Voudouris K, Tiniakos L, Kallergis G. Impacts of simultaneous action of drought and overpumping on quaternary aquifers of glafkos basin (Patras Region, Western Greece). Environ Geol 1996;29(3):209-215.

Lin MC, Liao CM, Liu CW, Singh S. Bioaccumulation of arsenic in aquacultural large-scale mullet Liza macrolepis from blackfoot disease area in Taiwan. Bull Environ Contam Toxicol 2001;67:91-97.

Liu TM. Fluorescent compounds in drinking water of blackfood disease endemic areas. Master Thesis. Taiwan: Institute of Biochemistry, College of Medicine, National Taiwan University, 1986. (pp. 21).

Liu CW, Lin WS, Shang C, Liu SH. The effect of clay dehydration on land subsidence in Yun-Lin coastal area, Taiwan. Environ Geol 2001;40(4-5):518-527.

Lu FJ, Yamamura Y, Yamauchi H. Studies on the fluorescent compounds in water of a well in blackfoot disease endemic areas in Taiwan: humic substances. J Formosan Med Assoc 1988;87:66-75.

Lu FJ. Blackfoot disease. Lancet 1990;2:442.

Lynn S, Shiung JN, Gurr JR, Jan KY. Arsenite simulates poly (ADP-ribosylation) by generation of nitric oxide. Free Radical Biol Med 1998;24(3):442-449.

Manning BA, Goldberg S. Adsorption and stability of arsenic (3) at the clay mineral-water interface. Environ Sci Technol 1997;31:2005-2011.

Matalas CN, Reiher JB. Some comments on the use of factor analysis. Water Resour Res 1967;3(1):213-223. 
Morsy MA. An example of application of factor analysis on geochemical stream sediment survey in Umm Khariga area, Eastern Desert, Egypt. Math Geol 1993;25(7):833-850.

Nickson R, McArthur J, Burgess W, Ahmed KM, Ravenscorft $\mathrm{P}$, Rahman M. Arsenic poisoning of Bangladesh groundwater. Nature 1998;395:338.

Reeve AS, Siegel D, Glaser PH. Geochemical controls on peatland pore water from the Hudson bay lowland: a multivariate statistical approach. J Hydrol 1996;181:285304.

Reyment RA, Joreskog KH. Applied factor analysis in the natural sciences. Cambridge, England; New York, NY, USA: Cambridge University Press, 1993. p. 371.

Saager R, Esselaar PA. Factor analysis of geochemical data from the basal reef, Orange Free State Goldfield, South Africa. Econ Geol 1969;64(4):441 -445.

Shen SB. Study on land subsidence in coastal plains in YunLin area (I). Conference on Land Subsidence, Taiwan 1989. p. $191-211$.

Stiff HA. The interpretation of chemical analysis by means of patterns. J Petrol Technol 1951;3:15-17.

Tainan Hydraulic Laboratory. The Yun-Lin offshore industrial infrastructure complexes planning, development and monitoring report part I, vol. 6, groundwater level and quality measurements. Taiwan, ROC: National Cheng-Kung University, 1992-1998.
Tsao YS, Wang JL. A comprehensive study of sea water intrusion for the Yun-Lin aquifer system. Taiwan: Agricultural Engineering Research Center, 1984. (pp. 159).

Tseng WP. Effects and dose-response relationships of skin cancer and blackfoot disease with arsenic. Environ Health Perspect 1977;19:109-119.

USPHS. Toxicological profile for arsenic. Washington, DC: USPHS, 1989.

Vine JD, Tourtelot EB. Geochemistry of black clay deposits: a summary report. Econ Geol 1970;65:253-272.

Voudouris KS, Lambrakis NJ, Papatheodorou G, Daskalaki P. An application of factor analysis for the study of the hydrogeological conditions in Plio-Pleistocene aquifers of NW Achaia (NW Peloponnesus, Greece). Math Geol 1997;29(1):43-59.

Yang HL, Hseng UC, Lu FJ, Tasi HD. Humic acid reduces proten-C-activating cofactor activity of thrombomodulim of human umbilical vein endothelial cells. $\mathrm{Br} \mathrm{J}$ Haematol 1998;101:16-23.

Yeh SJ, Yang MH. Traces elements in water samples from endemic area of blackfoot disease and biospecimens from blackfoot disease patients: a preliminary report. Blackfoot Dis Resour Rep 1980;8:22-28.

Zhang J, Snyder SH. Nitric oxide stimulates auto-ADP-ribosylation of glyceraldehyde-3-phosphate dehydrogenase. Proc Natl Acad Sci USA 1992;89:9382-9385. 